\title{
ERRATUM 4
}

Article "Evaluation of the performance of the modified early warning score in a Brazilian public hospital", with number of DOI: http://dx.doi.org/10.1590/0034-7167-2017-0537, published in the journal Revista Brasileira de Enfermagem, v72(6):1428-34, on page 1428:

Where it read:

\section{Carlos Henrique Miranda Rodrigues'}

ORCID: 0000-0002-4420-6401

Montenegro SMSL, Rodrigues CHM. Evaluation of the performance of the modified early warning score in a Brazilian public hospital. Rev Bras Enferm. 2019;72(6):1428-34. doi: http://dx.doi.org/10.1590/0034-7167-2017-0537

Read:

\section{Carlos Henrique Miranda'}

ORCID: 0000-0002-5968-4879

Montenegro SMSL, Miranda CH. Evaluation of the performance of the modified early warning score in a Brazilian public hospital. Rev Bras Enferm. 2019;72(6):1428-34. doi: http://dx.doi.org/10.1590/0034-7167-2017-0537 